\title{
Legal Definition of the Decision of General Meeting in the Russian Law
}

\author{
Gazizullina L.Z.
}

Kazan Federal University, Institute of Management, Economics and Finance, Kazan, 420008, Russia

\section{Doi:10.5901/mjss.2015.v6n1s3p11}

\begin{abstract}
In the clause the concept "the meeting decision" in civil law of the Russian Federation and foreign countries is analyzed. The author considers the legal nature of the decision of meeting on an example of decisions of general meeting of proprietors of premises, copartners of proprietors of habitation, analyzes bases of its invalidity, a consequence of acknowledgement of the decision of meeting of proprietors of premises, copartners of proprietors of habitation void, studies the moment from which the meeting decision is considered void, and also the persons having the right to the appeal of decisions of specified meetings. It is necessary to notice that for today in Russia the substantive provisions, meetings concerning decisions are legislatively established only, and foreign scientists-jurists state considerable number of assumptions of their legal nature. The specified circumstances induce to research, first of all, assumptions and conclusions of foreign authors and to the further rather-legal analysis.
\end{abstract}

Keywords: The meeting decision, partnership of proprietors of habitation, general meeting of proprietors of premises, general meeting of copartners of proprietors of habitation, invalidity of the decision of meeting.

\section{Introduction}

In a science of civil law of Germany [1; 2] there is a concept of "decision" to which carry decisions of general meetings, the supervisory boards, other controls of economic societies, and also other consolidations and organisations: connections physical and juridical persons, capable and not capable consolidations or people [3]. The specified decisions concern, including decisions of participants of condominiums [4]. However general provisions about decisions of meetings in the legislation of Austria, Germany, Switzerland are absent.

Foreign researchers determine the decision as "technics collective will" [5; 6], but it is thus specified that the will of separate persons is generalised in the decision.

From the point of view of foreign researchers, specificity of the decision of meeting is that it is not declaration of will, but is based on separate declarations of will: on voting of shareholders or other partners. R. Bork, leaning against court practice and the doctrine, notices that the decision of meetings consists of set in parallel flowing, under the maintenance unanimous, namely expressed in the form of the voting, those declarations of will who participates in decision-making [7]. Thus the meeting decision is considered accepted if for its accepting everything have voted not, and the majority of the persons participating in voting. Besides to the meeting decision should submit including the persons who have not taken part in voting and even not consent. V. Boeken asserts that the meeting decision represents the legal transaction with several unidirectional declarations of will. Such orientation, in its opinion, distinguishes the decision from the agreement which also represents the multilateral legal transaction, however is characterised by mutual declarations of will [8]. In turn, V. Flum, leaning against court practice, specifies that the decision represents not the sum of separate declarations of will, and their interaction at participation in decision-making [9].

\section{Theory}

In the acting Russian legislation decisions of various meetings are provided. Bases of their invalidity, a consequence of their acknowledgement are legislatively fixed by those, and also the moment from which the meeting decision is considered void is specified. So, decisions of participants of the legal entity admit Russia (including the decision of general meeting of shareholders, participants of restricted liability society, housing memory co-operative society, copartners of proprietors of habitation and others); and also decisions of general meeting of proprietors of premises in an apartment house.

The Civil code of the Russian Federation determines the meeting decision as follows: "the meeting Decision with which the law connects civil-law consequences, generates legal consequences on which the decision it is directed, for all 
persons, having the right to participate in the given meeting (participants of the legal entity, joint owners, creditors at bankruptcy and others - participants of civil-law community), and also for other persons when it is established by the law or follows from a being of relations" [10]. The given formulation of the decision of meeting as bases of origin of civil laws and obligations, in our opinion, allows to draw a conclusion that it cannot be carried to transactions.

In the Russian right the analysis of the legal nature of decisions of meetings is performed in a context of interpretation of the legislation on juridical persons. So, N.V. Kozlova considers that all acts of an internal of juridical persons including their decisions, represent itself as multilateral transactions [11]. G.S. Shapkin underlines that "decisions, as a rule, mention the rights and legitimate interests of shareholders, but not as the persons acting as the party in the transaction, and as participants of a society within the limits of the corporate relations regulated by special precepts of law" [12].

Other scientists, analyzing the legal nature of acts of controls of the legal entity, determine such acts as local normative acts [13]. The third group of scientists believes that decisions of controls of the legal entity are not standard legal acts $[14 ; 15]$.

V.I. Dobrovolsky's position which considers that is impossible, obviously to regard the decision of meeting as not standard legal act as relations in a society are not public or administrative and are based exclusively on the civil legislation as the transaction directed on an establishment, change or the termination of the rights and obligations [16], proves to be true court practice materials. It is necessary to notice that it, regarding the decision of general meeting of shareholders exclusively as the act of the supreme body of management of a society, notices that the meeting decision is a basis for the conclusion of the large transaction or the transaction in which fulfilment there is an interest, and the decision of meeting on election of board of directors and (or) the general director generates powers of controls joint stock company and, as consequence, powers on fulfilment of transactions. Thus any conclusions concerning the legal nature of the decision of meeting are not made.

\section{Findings and Discussion}

Features by which decisions of meetings are allocated, allow to carry them to special type of dispositive facts. The given circumstance proves to be true V.S. Em's position [17] and A.E. Sherstobitov [18] which believe that the meeting decision as the corporate act, undoubtedly, can be carried to special dispositive facts of civil law.

It is necessary to agree with O.M. Rodionova's opinion which believes that any of these approaches to understanding of the nature of decisions of controls the juridical person cannot be accepted on unique, but to very significant basis: bodies of the legal entity are not persons of law, hence, cannot make any legally significant actions, including transactions, not standard legal acts, etc. [19]

\subsection{Invalidity of decisions of meetings and its kinds}

In a German science it is supposed that decisions of meetings can be recognised by void by general rules about invalidity of the transactions, provided by civil codes. For acknowledgement void decisions of general meetings of joint stock companies, restricted liability societies [20], decisions of condominiums of [21] and other communities laws establish special rules.

Division of nullity decisions on insignificant and debatable is represented reasonable as bases for invalidity of decisions of meetings a little, and the illegality of several of them is obvious and, as a rule, does not demand judicial consideration. Besides, such division is claimed by court practice.

In item 181.3 the Civil code of the Russian Federation decisions of meetings are divided on insignificant and debatable. Just as in the German joint-stock right it is fixed that the meeting decision can be nullified on the bases established by the law, owing to acknowledgement by its that court (debatable the decision) or irrespective of such acknowledgement (insignificant the decision). By analogy to the German legislation position about an order of confirmation of decisions of meetings is entered. So, in item 2 of item 181.4 the Civil code of the Russian Federation it is told: "the meeting Decision, debatable in connection with infringement of an order of its accepting, cannot be challenged, if it is confirmed appropriate repeated by the decision before acknowledgement by its court void".

Division of decisions of meetings into the insignificant and debatable has found continuation in a designation of corresponding methods of protection: possibility of acknowledgement of the decision is fixed by the void. Voidability of the decision disappears, if general meeting has confirmed disputable the decision new and it has not been appealed during term of contest or contest has been refused. 


\subsection{Bases of invalidity of decisions of meetings}

In the acting Russian legislation the positions similar to the German joint-stock legislation are provided: so, 4.5 items 46 of the Housing code of the Russian Federation the right to appeal in court gives to proprietors of premises in an apartment house the decision, accepted by general meeting of proprietors of premises in the given house with infringement of requirements of the law, in a case if it did not accept participation in this meeting or voted against accepting such decisions and if such the decision breaks its rights and legitimate interests) [22].

The Russian legislator also uses criterion of importance. So, in item 6 of item 46 of the Housing code of the Russian Federation it is established that the court taking into account all circumstances of business has the right to uphold обжалуемое the decision if voting of the specified proprietor could not affect results of the voting, the admitted infringements are not essential and the agreed conclusion has not caused causing of losses to the specified proprietor.

In item 4 of item 181.4 the Civil code of the Russian Federation it is told: "the meeting decision cannot be nullified, if voting of the person which rights are mentioned challenged by the decision, could not affect its accepting and the decision does not attract essential adverse consequences for this person". It means that acknowledgements of the decision of meeting void both circumstances should be present simultaneously. However, it is necessary to notice that determination of "essential adverse consequences" in the legislation is absent.

It is thought, importance of infringement should not be a basis of invalidity of the decision of meeting if it is not legislatively specified how it is made in other cases of the use in the term current legislation "essential". For example, in item 1 of item 178 the Civil code of the Russian Federation is established importance of error and its explanatory is given. Also in item 432 the Civil code of the Russian Federation that concerns essential treaty provisions is specified.

Let's agree with O.M. Rodionova's determination which by analogy to determination in item 2 of item 450 the Civil code of the Russian Federation of fundamental breach of the agreement in which interpretation there is a considerable experience, would solve a problem of division of infringements on attracting and not attracting causing suggests to understand as essential adverse consequences to the participant of community of such harm invalidity of decisions of meetings "that it substantially loses that, on what have the right was to count, having the right to vote" [16].

\subsection{Consequences of acknowledgement of decisions of meetings the void}

Any consequences of acknowledgement of decisions of meetings void in the Civil code of the Russian Federation it is not fixed. This question till today has not found the decision in the acting Russian legislation. In a science and practice the problem is shined with reference to decisions of separate kinds of meetings.

So, researchers mark an ambiguity of consequences of acknowledgement void decisions of general meetings. As to acknowledgement consequences void decisions of meetings of general meetings of proprietors of premises or copartners of proprietors, about it the legislator at all speaks nothing.

Consequences of invalidity of the decision, considering it регулятивный character, transactions, and the state structure or local government act (item 13 the Civil code of the Russian Federation) are similar to invalidity consequences not. In this connection it would be logical by analogy to paragraph 2 of item 13 the Civil code of the Russian Federation to fix in the Civil code of the Russian Federation a rule that in case of acknowledgement by court of the decision of meeting void the broken right is subject to restoration or protection by the different ways provided by the law.

Taking into account told it is represented what followed give to considered position more general character and to fix in the Civil code of the Russian Federation the prescription that acknowledgement of decisions of meeting about fulfilment of transactions void in case of the appeal of such decisions separately from contest of corresponding transactions does not involve acknowledgement of corresponding transactions by the void.

\subsection{The persons having the right to the appeal of decisions of meetings}

In the current legislation, and in the Civil code of the Russian Federation a circle of persons, having the right to appeal against the meeting decision, it is limited by those who is anyhow connected with its accepting. In item 3 of item 181.4 the Civil code of the Russian Federation it is specified that the participant of the corresponding civil-law community not accepting participations in meeting or voting against accepting challenged decision has the right to challenge the meeting decision in court. Thus under participants of community in item 181.1. The persons are understood, first of all, having the right to participate in the given meeting: participants of the legal entity, joint owners, creditors at bankruptcy, etc. However the specified possibility is not excluded and for other persons when it is established by the law or follows from a being of relations. 
In the current legislation a circle of persons, having the right to appeal against decisions of meeting of participants of juridical persons and joint owners, it is limited only by the authorised persons. So, in item 6 of item 46 of the Housing code of the Russian Federation it is fixed that the proprietor has the right to appeal against the decision in court, accepted by general meeting of proprietors of premises in the given house with infringement of requirements the Housing code of the Russian Federation in case it did not take part in this meeting or voted against accepting such decisions and if such the decision breaks its rights and legitimate interests.

The right to the appeal cannot be transferred the authorised person to other person as has personal character. The given circumstance has great value when the question on possibility of the appeal of the decision of general meeting of proprietors of premises or general meeting of copartners of proprietors of habitation by the persons who have become by proprietors of corresponding object of real estate or copartners of proprietors of habitation after its accepting is solved.

With reference to general meeting of copartners of proprietors of habitation the meeting decision - the internal act of the specified meeting which is created by its participants during their activity during the concrete moment of time. For decision-making by meeting two factors matter: voting of copartners and the decision statement. The first cannot be performed at any time. It is limited by the frameworks specified by the law: the copartner of proprietors of habitation has the right to vote during the moment which has been taken away for this purpose at meeting, or in other established order, but not when will solve itself. Therefore, as it is truly marked by courts, the person who was present at meeting, but did not vote, has not exercised the right, did not participate in decision-making, cannot demand acknowledgement of the decision by the void. All other persons do not concern the meeting decision, as it is not published, not expressed for them. Even if the subject becomes subsequently the participant of meeting, it can challenge only new the decision, but not already accepted. Accordingly, the new member of meeting if its rights and interests are broken by the decision, as well as any interested persons, can challenge only actions (for example, the transactions made after decision-making by meeting) which element it will be.

Thus the satisfaction of the requirement about invalidity of the decision of meeting is supposed possible if voting of the person which rights are mentioned challenged by the decision, could affect its accepting and the decision attracts essential adverse consequences for this person (item 4 of item 181.4 the Civil code of the Russian Federation).

Results of comparison of general meeting of proprietors of premises and general meeting of copartners of proprietors of habitation by various criteria are displayed in table №1 which can assist at the organisation and carrying out of the specified meetings.

Table 1. The comparative table of meeting in partnership of proprietors of habitation

\begin{tabular}{|c|c|c|c|}
\hline \multicolumn{2}{|c|}{ General meeting of proprietors of premises } & \multicolumn{2}{|c|}{ General meeting of copartners of proprietors of habitation } \\
\hline $\begin{array}{c}\text { In the form of a joint } \\
\text { presence }\end{array}$ & In the form of correspondence voting & $\begin{array}{l}\text { In the form of a joint } \\
\text { presence }\end{array}$ & In the form of correspondence voting \\
\hline \multicolumn{4}{|c|}{ General meeting place in system of controls an apartment house } \\
\hline \multicolumn{2}{|r|}{ Controls an apartment house } & \multicolumn{2}{|c|}{$\begin{array}{l}\text { The supreme body of management of partnership of proprietors of } \\
\text { habitation }\end{array}$} \\
\hline \multicolumn{4}{|c|}{ Regulation of an order of convocation } \\
\hline \multicolumn{2}{|c|}{ The housing code of the Russian Federation } & \multicolumn{2}{|c|}{$\begin{array}{l}\text { The housing code of the Russian Federation and the partnership } \\
\text { charter }\end{array}$} \\
\hline \multicolumn{4}{|c|}{ Features of carrying out } \\
\hline- & $\begin{array}{c}\text { Can be conducted only in case of absence of } \\
\text { quorum at internal meeting }\end{array}$ &. & $\begin{array}{c}\text { Can be conducted only in case of absence of } \\
\text { quorum at internal meeting }\end{array}$ \\
\hline \multicolumn{4}{|c|}{ Data which should be specified in the message / the notification } \\
\hline The list is contained in & $\begin{array}{l}\text { item } 5 \text { of item } 45 \text { of the Housing code of the } \\
\text { Russian Federation }\end{array}$ & \multicolumn{2}{|c|}{$\begin{array}{l}\text { The list is contained in item } 2 \text { of item } 146 \text { of the Housing code of the } \\
\text { Russian Federation }\end{array}$} \\
\hline \multicolumn{4}{|c|}{ Quorum } \\
\hline \multicolumn{2}{|c|}{$50 \%$ of voices from total of voices of proprietors } & \multicolumn{2}{|c|}{$\begin{array}{c}50 \% \text { of voices from total of voices of copartners of proprietors of } \\
\text { habitation }\end{array}$} \\
\hline \multicolumn{4}{|c|}{ The initiator of carrying out of meeting } \\
\hline \multicolumn{2}{|r|}{ The proprietor (proprietors) } & \multicolumn{2}{|c|}{ Any member (members) of partnership } \\
\hline \multicolumn{4}{|c|}{ Leads meeting } \\
\hline $\begin{array}{c}\text { The selected } \\
\text { chairman of meeting }\end{array}$ & - & $\begin{array}{l}\text { The chairman of the } \\
\text { board or the trustee }\end{array}$ & - \\
\hline \multicolumn{4}{|c|}{ The competence } \\
\hline It is specified in iter & $\begin{array}{l}\text { m } 2 \text { of item } 44 \text { of the Housing code of the } \\
\text { Russian Federation }\end{array}$ & It is specified in item $2 \mathrm{C}$ & $\begin{array}{l}\text { item } 145 \text { of the Housing code of the Russian } \\
\text { Federation }\end{array}$ \\
\hline
\end{tabular}




\section{Concluding Remarks}

So, summing up concerning short research of the legal nature of decisions of meetings and their invalidity, it is necessary to notice, first of all, that entered into the Civil code of the Russian Federation new positions have first of all functional character and are caused by practical requirements of civil turnover. The generalisation expressed in these positions, have more likely intuitive character, than are a consequence of carefully developed theory as the approach to the decision as to the transaction which dominates in the German doctrine, is almost unanimously rejected both the Russian scientists, and experts. Thus any of own theoretical positions has not received wide recognition. At the same time the majority of the positions, decisions of meetings concerning to the legal nature, has been adopted from foreign, in particular, the German joint-stock right.

In our opinion, the meeting decision - legally significant actions of citizens, juridical persons, and also the municipal unions, directed on origin, change and the termination of civil, corporate, organizational and other legal relationship.

\section{References}

Boecken W. BGB - Allgemeiner Teil. W. Kohlhammer Verlag, 2007. - pp. 23-24.

Bork R. Allgemeiner Teil des Burgerlichen Gesetzbuchs. - Tubingen, 2006. -pp. 167

Bub R.R. Der Mehrheitsbeschluss der Wohnungseigentumer. - Koln, 2000. - pp. 26

Filzek M. Kostenordnung: Gesetz uber die Kosten in Angelegenheiten der freiwilligen Gerichtsbarkeit (KostO). - Berlin, 2006. - pp. 240

Flume W. Allgemeiner Teil des Burgerlichen Rechts. Bd. 1. Teil 2: Die juristische Person. - Springer, 1983. - pp. 12-13.

Hubner H. Allgemeiner Teil des Burgerlichen Gesetzbuches. - Berlin; NY, 1995. - pp. 282

Medicus D. Allgemeiner Teil des BGB. - Heidelberg; Munchen; Landsberg; Frechen; Hamburg, 2010. - pp. 93

Picout S. Relevanz oder Kausalitat: Zur Beziehung zwischen dem VerstoS gegen die Rechtsordnung und der Rechtswidrigkeit eines Beschlusses von Kapitalgesellschaften bei Verfahrensfehlern. - Koln, 2012. - pp. 6

Schmidt K. Gesellschaflsrecht. - Koln; Berlin; Bonn; Munchen, 2002. - pp. 9-11

Wohnungseigentum: Kommentar - Antrage - Entscheidungen / F. Lenk (Hg.). -2010. - pp.61-62

Civil code of the Russian Federation (a part the first) 30/11/1994 №51 // Legislation meeting. - 05.12.1994. - №32. - Item 3301

Dobrovolsky V.I. Judicial protection of the rights of the shareholder (participant) - questions of application of the right // Bulletin of the Supreme Arbitration Court of the Russian Federation. - 2005. - №4 - 5.

Housing code of the Russian Federation 29/12/2004 №188 // Legislation Meeting. - 1/3/2005. - №1. - Item 14

Kozlova N.V. Legal personalit of the legal entity. - M: Statute, 2005. - pp. 56-58.

Lomakin D.V. Corporate of legal relationship: the general theory and practice of its application in economic societies. - M: Statute, 2008/ - pp. 43-44.

Rodionova O.M. About the legal nature of decisions of meetings and their invalidity in the German and Russian civil law // Civil law Bulletin. - 2012. - №3. - p. 12.

The Russian civil law: the Textbook / E.A. Sukhanov. - M: Statute, 2011. - pp. 156.

Tarasenko J.A. Term on the appeal of decisions of general meeting // Justice in the Volga region. - 2004. - №5. - pp. 7-8

Shapkin G. S. Application of the joint-stock legislation. - M: Statute, 2009. - pp. 4-6

Abdreev T.I., Tufetulov A.M. Legal status of an appraiser in the Russian Federation under globalization // Mediterranean Journal of Social Sciences vol. 5 № 24, November 2014, pp. 188-192.

Bagautdinova N.G, Safiullin L.N, Badrtdinov N.N The Role of Consumer Expenses in Ensuring Forward Dynamics of The Russian Economy// Mediterranean Journal of Social Sciences.- Vol.5, No12, (2014)-pp.43-48. 